\title{
Determination of microamounts of iron by hydroxamate resin colorimetry
}

\author{
Chuen-Ying Liu, Huan-Tsung Chang, and Liang-Jiun Uang \\ Department of Chemistry, National Taiwan University, Taipei, Taiwan, Republic of China
}

\section{Bestimmung von Mikromengen Eisen durch Hydroxamatharz-Colorimetrie}

Summary. A new, sensitive chelating ion-exchanger colorimetric method has been developed for the determination of iron at the $\mu \mathrm{g} / \mathrm{l}$ level in water, based on the direct measurement of light absorption of iron hydroxamate resin complex. In $0.2 \mathrm{~N}$ perchloric acid solution, iron could be rapidly, selectively and quantitatively absorbed on the hydroxamate resin. The calibration curve for iron(III) of a $25 \mathrm{ml}$ solution was linear in the concentration range $8.00 \times 10^{-6}$ to $5.00 \times 10^{-5} \mathrm{M}$. For iron(III) with larger sample volumes, the relative detection limit was increased. Most of the metals interfered negligibly, such as $\mathrm{Ca}(\mathrm{II}), \mathrm{Co}(\mathrm{II}), \mathrm{Cu}(\mathrm{II}), \mathrm{Ni}(\mathrm{II})$ and $\mathrm{Zn}$ (II), except for higher concentration of lead(II) and mercury(II) when present at up to 400 times the concentration of iron(III). The effects of EDTA, glycine, thiourea, phosphate, nitrate and chloride on the retention of iron(III) were also examined. Only thiourea significantly influenced the retention of iron(III). The presence of sodium chloride even at a concentration of $3.5 \times 10^{4}$ times that of iron(III) did not interfere at all.

\section{Introduction}

At present, a continuous growth in demands for a quantitative determination of extremely low amounts of various elements in analyzed material can be observed, especially in connection with environmental and biochemical analysis, in semiconductors, extraterrestrial materials, and high-purity metals, etc.

The use of ion exchangers in extreme trace analysis is generally limited by two sources of error:

a) contamination of the eluate by the resin (traces of metals or organic material from the resin)

b) irreversible adsorption of small quantities of material.

The first one can be suppressed by a thorough purification of sorbants used and the second one - an incomplete recovery of adsorbed ions - can be avoided by ashing the resin (either in air or in oxygen plasma) and by determining the trace ions in the ash or by determining the trace elements directly in the resin by the application of a suitable instrumental method, such as X-ray fluorescence, neutron activation analysis, etc. However, these methods are not so convenient.

Offprint requests to: Chuen-Ying Liu
Hydroxamic acids, -CONHOH, have long been recognized for their special ability to form complexes with heavy metals, particularly iron(III) [1-4]. The intense colors and the high stabilities of many of these complexes has led to the development of various analytical procedures based upon these reactions $[5-6]$.

We have synthesized a hydroxamate resin based on the polyacrylonitrile-divinylbenzene copolymer and studied the chelating behavior of this resin towards molybdenum(VI), uranium(VI), vanadium(V) and tungsten(VI) [7]. In this paper, a new, sensitive, selective microdetermination method for iron(III) in water has been developed, based on direct measurement of the absorbance of the colored complex of iron-hydroxamate resin. It takes advantage of chelating resin properties, such as concentration, selective sorption and simultaneous color development on the resin phase.

\section{Experimental}

Apparatus. Spectrophotometric measurements were performed with the Hitachi Digital Spectrophotometer (model 624) and a Hitachi automatic recorder (model QD 15).

The quartz cell used was the same as that used by Yoshimura [8].

Preparation of hydroxamate resin. Hydroxamate resin was synthesized from Amberlite IRC-50 cation exchanger and hydrogen chloride-free hydroxylamine at $\mathrm{pH} 8-9$ and $70^{\circ} \mathrm{C}$ in methanol. The detailed procedure was described in the previous paper [7]. The hydrogen form of the prepared resin $(60-100$ mesh) was used.

Procedure for the determination of iron(III). To a water sample containing $0.2 \sim 1.25 \mu$ mole of iron(III), $5 \mathrm{ml} 1 \mathrm{~mol} / \mathrm{l}$ perchloric acid was added to make a total volume of $25 \mathrm{ml}$ and the concentration of the acid approximately $0.2 \mathrm{~mol} / 1$. Then $0.3 \mathrm{~g}$ of the resin was added. The mixture was stirred for $30 \mathrm{~min}$ and the colored resin slurry was transferred to the cell. The absorbances at $500 \mathrm{~nm}$ were measured.

Distribution measurements. To two water samples containing $1.08 \mu \mathrm{mol}$ of iron(II) and iron(III), respectively, $5 \mathrm{ml} 1 \mathrm{~mol} / 1$ perchloric acid was added to each make a total volume of $25 \mathrm{ml}$ and the acid concentration approximately $0.2 \mathrm{~N}$ and then $0.3 \mathrm{~g}$ of the resin was added. After a $30-\mathrm{min}$ equilibration, the amount of metal ion sorbed on the resin was determined by chelating ion-exchanger colorimetry. The distribution ratio, $D$, was calculated from 


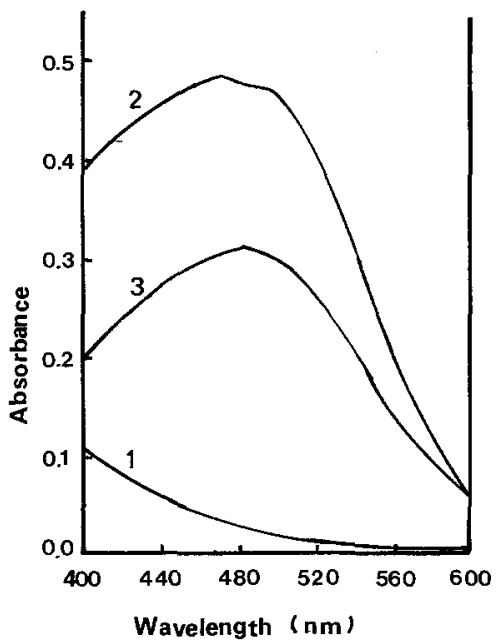

Fig. 1. Absorption spectrum. 1 Hydroxamate resin; 2 iron-hydroxamate resin complex; 3 iron-ferroxamine B complex [9]

$D=\frac{\text { mmol of iron sorbed per } \mathrm{g} \text { of resin }}{\text { mmol of iron per } \mathrm{ml} \text { of solution }}$

Formation constant. From $1 \times 10^{-3}$ to $4 \times 10^{-3} \mathrm{mmol}$ of EDTA, the external complexing agent, and $4.9 \times 10^{-4}$ to $2.49 \times 10^{-3} \mathrm{mmol}$ of ferric ion were mixed with 0.15 to $0.50 \mathrm{~g}$ of resin. The acidity of the solution was adjusted to $\left[\mathrm{H}^{+}\right]=$ $0.2 \mathrm{~N}$. The mixtures were equilibrated for $48 \mathrm{~h}$ and the samples were then filtered and washed thoroughly with deionized water. The quantity of metal ions absorbed on the resin was determined directly with the procedure described in this paper.

\section{Results and discussion}

Effect of $p H$ on the recovery of iron(III). The results of the recovery of iron(III) from an aqueous solution of various $\mathrm{pH}$ showed that iron(III) could be quantitatively retained either from aqueous solution of $\mathrm{pH}>3$ or from $0.2 \mathrm{~N}$ perchloric acid solution. In this paper, the latter was used for retaining iron(III) in the sample solution, because with this acidity iron(III) could be selectively separated from the other common heavy metal ions by the hydroxamate resin.

Effect of shaking time. The retention of iron(III) from $0.2 \mathrm{~N}$ perchloric acid solution was examined at various shaking times. The results showed that iron(III) retained rapidly on the hydroxamate resin and took only $20 \mathrm{~min}$ to reach completion.

Absorption spectrum. In Fig. 1, curve 1 shows the absorption spectrum of hydroxamate resin and curve 2 the absorption spectrum of iron(III) sorbed on the hydroxamate resin. Maximum absorbance of this complex was at $500 \mathrm{~nm}$. Curve 3 shows the absorption spectrum of iron-ferrioxamine B complex [9]. It is seen that the iron-hydroxamate resin spectrum (Curve 1) is similar to that of the iron-hydroxamic acid monomer complex (Curve 3).

Calibration. The calibration curve for iron(III) of a $25-\mathrm{ml}$ solution was linear in the concentration range $8.00 \times 10^{-6}$ to $5.00 \times 10^{-5} \mathrm{M}$. For five determinations, the standard deviations were only $\pm 0.003 \sim \pm 0.009$.
Table 1. Effects of foreign ions on the determination of $0.196 \mu$ mole of iron(III)

\begin{tabular}{llllc}
\hline & $\begin{array}{l}\text { Added molar } \\
\text { ratio to } \mathrm{Fe}\end{array}$ & $\begin{array}{l}\mathrm{A}_{\mathrm{RC}} \\
(500 \mathrm{~nm})\end{array}$ & $\begin{array}{l}\text { Fe found } \\
(\mu \text { mole })\end{array}$ & $\begin{array}{l}\text { Relative } \\
\text { error }(\%)\end{array}$ \\
\hline- & - & 0.113 & 0.196 & 0 \\
$\mathrm{Co}(\mathrm{II})$ & 510 & 0.118 & 0.197 & +0.76 \\
$\mathrm{Ni}(\mathrm{II})$ & 495 & 0.121 & 0.207 & +5.47 \\
$\mathrm{Cu}(\mathrm{II})$ & 510 & 0.113 & 0.196 & 0 \\
$\mathrm{Zn}(\mathrm{II})$ & 510 & 0.113 & 0.196 & 0 \\
$\mathrm{~Pb}(\mathrm{II})$ & 49.5 & 0.115 & 0.196 & 0 \\
& 495 & 0.118 & 0.197 & +0.76 \\
$\mathrm{Hg}(\mathrm{II})$ & 49.5 & 0.114 & 0.196 & 0 \\
& 200 & 0.121 & 0.207 & +5.47 \\
$\mathrm{Ca}(\mathrm{II})$ & 128 & 0.112 & 0.196 & 0 \\
$\mathrm{PO}_{4}^{3-}$ & 128 & 0.115 & 0.196 & 0 \\
$\mathrm{NO}_{3}^{-}$ & 128 & 0.114 & 0.196 & 0 \\
\hline
\end{tabular}

Sensitivity. The distribution ratio for iron(III) of a $25 \mathrm{ml}$ sample solution was 1250 , while for iron(II) in the presence of ascorbic acid it was only 238 . However, if iron(II) was present in the absence of ascorbic acid, some iron(II) might be oxidized to iron(III) and eventually all iron(II) was oxidized, and the distribution ratio of iron(II) was nearly equal to that of iron(III). For iron(III) with larger sample volumes such as a $1500 \mathrm{ml}$, the relative detection limit increased (the concentration that produced an absorbance equal to that of a $25 \mathrm{ml}$ sample solution) to $1.31 \times 10^{-7} \mathrm{M}$, with $25 \mathrm{ml}$ it was $7.84 \times 10^{-6}$.

Formation constant. The formation constant of iron-hydroxamate resin complex were measured by the method of Loewenschuss and Schmuckler [10]. This involved a competition of the ferric ion between resin and an external EDTA solution. The equation used to determine $K_{\mathrm{MR}}$, the formation constant of the resin for the metal ion, was

$\log K_{\text {overall }}=\log K_{\mathrm{MR}}-\log K_{\mathrm{MY}}=\log \frac{[\mathrm{MR}][\mathrm{Y}]}{[\mathrm{MY}]}-\log [\mathrm{R}]$.

The conditional formation constant obtained was $10^{4.44}$ The dissociation constant of the hydroxamate resin measured potentiometrically in the previous paper [7] was $10^{-6.47}$. In $0.2 \mathrm{~N}$ perchloric acid solution, $\alpha$ value of the hydroxamic acid resin could be calculated from the equation, $\mathrm{Ka} /\left[\mathrm{H}^{+}\right]$ $+K a$. The formation constant for the iron-hydroxamate resin complex, $10^{10.21}$, agreed fairly well with the corresponding constant of the hydroxamate monomer (acetohydroxamic acid), $10^{11.42}$ [9].

Effect of various substances on the retention of iron(III). Various metal ions that might react with hydroxamate resin were examined for their effect on the absorption procedure. The results are shown in Table 1. Most of the metals did not interfere, except for higher concentrations of lead(II) and mercury(II) when present at up to 400 times the concentration of iron(III).

The effects of EDTA, glycine and thiourea on the retention of iron(II) were also examined. Only thiourea significantly influenced the retention of iron(III), even at $0.2 \mathrm{~N}$ perchloric acid solution by considerably decreasing it. When comparing the conditional constant of iron-resin complex with those of iron-EDTA and iron-glycine [11], the above phenomenon was quite obvious. 
The presence of sodium chloride even at a concentration 35000 times that of iron(III) did not interfere at all. Thus, the suggested method was an excellent technique for the determination of iron(III) in high concentrations of electrolyte.

Application of chelating ion-exchanger colorimetry. The method was applied to the determination of iron(III) in standard reference material of NBS, No. $1643 \mathrm{~b}$ (trace elements in water) and natural water samples, such as tap water and rain water. The concentration of iron(III) in the standard was $110 \mu \mathrm{g} / 1$, being somewhat higher than the true value $(99 \pm 8 \mu \mathrm{g} / 1)$, while that of the tap water at different places was varying. The iron(III) concentration of tap water I was $205 \mu \mathrm{g} / \mathrm{l}$, that of tap water II was only $14.6 \mu \mathrm{g} / \mathrm{l}$. When the tap water I was passed through $0.45 \mu \mathrm{m}$ filter before determination, the concentration of iron(III) decreased to under detection level. Hence, the high concentration of iron(III) in tap water I might be due to the corrosion of tubing. The iron(III) concentration of rain water sampled in Taipei area was $22.3 \mu \mathrm{g} / 1$. The results of five determination for each sample were highly reproducible.

\section{Conclusion}

The suggested method for the determination of microamounts of iron(III) in water is (1) sensitive and selective (without any prior separation and preconcentration); (2) able to be applied in the presence of large amounts of other metal ions and sodium chloride (hence it is suitable for the determination of the iron content of high-electroyte samples, such as sea water and biological samples); (3) simple and reproducible.

Acknowledgement. This work was supported by a grant from the National Science Council of the Republic of China, to which great thanks are due.

\section{References}

1. Yale HL (1943) Chem Rev $33: 209$

2. Mathis F (1953) Bull Soc Chim Fr D9

3. Neilands JB (1966) Struct Bonding 1:59

4. Maehr H (1971) Pure Appl Chem 28:603

5. Bass VC, Yoe JH (1966) Talanta 13:735

6. Aksnes G (1957) Acta Chem Scand 11:710

7. Liu CY, Sun PJ (1986) Fresenius Z Anal Chem 325:553

8. Yoshimura K, Ohashi S (1978) Talanta 25:103

9. Schwarzenbach G, Schwarzenbach K (1963) Helv Chim Acta $46: 1390$

10. Loewenschuss H, Schmuckler G (1964) Talanta 11:1399

11. Martell AE, Smith RM (1974) Critical stability constants, vol 1. Plenum Press, New York

Received February 11, 1987 